\title{
CONTROL OF Botrytis cinerea IN Eucalyptus globulus MINI-CUTTINGS USING Clonostachys AND Trichoderma STRAINS
}

\author{
Salomé Zaldúa ${ }^{1}$, and Eugenio Sanfuentes ${ }^{1^{*}}$
}

\begin{abstract}
Botrytis cinerea Pers. ex Fr. causes the disease known as gray mold in more than 200 hosts. It is one of the most important pathogens in Chilean forest nurseries and Eucalyptus globulus Labill. is one of the most susceptible species, especially in vegetative reproduction systems. Clonostachys and Trichoderma strains were selected as potential biocontrol agents of gray mold in previous research by the authors. The objective of this study was to evaluate the effectiveness of antagonistic fungi to control B. cinerea in E. globulus mini-cuttings. Five fungi strains were tested and applied weekly, two Clonostachys and three Trichoderma $\left(5 \times 10^{6}\right.$ conidia $\left.\mathrm{mL}^{-1}\right)$. In addition, comparison treatments were also used: absolute control (water) and fungicide application. The experiment was carried out under operational conditions to produce E. globulus mini-cuttings. The Clonostachys UDC-A10 and UDC-A11 strains reduce mini-cutting mortality caused by $B$. cinerea in 54 and $71 \%$, respectively, and with effects similar to those achieved by fungicides. Clonostachys UDC-A11 reduces the disease progression rate with the same statistical results as fungicides. A negative effect of applying fungicides on rooting of the surviving mini-cuttings was also confirmed. These results demonstrate the effectiveness of Clonostachys as a control agent against gray mold disease in $E$. globulus mini-cuttings.
\end{abstract}

Key words: biocontrol agents, forest nurseries, eucalyptus, gray mold, antagonistic fungi.

\section{INTRODUCTION}

The Botrytis cinerea Pers. ex Fr. pathogen fungi causes gray mold disease in a wide variety of hosts (Coley-Smith et al., 1980; Elad et al., 2004), and is a serious economic problem in crops such as table grapes, vines, strawberries, raspberries, lettuce, cucumbers, broad beans, tomatoes, beans, flowers, and forest plants produced in containers (Elad et al., 2004).

Gray mold is an important sanitary problem in Pinus radiata D. Don and Eucalyptus globulus Labill. nurseries in Chile, and is especially severe in the latter species. Problems caused by $B$. cinerea have been observed in the majority of forest nurseries in the Southern Hemisphere (Butin and Peredo, 1986) with different disease incidence and severity levels, causing losses greater than $50 \%$ in some cases. In addition, in the last few years, it has caused

${ }^{1}$ Universidad de Concepción, Facultad de Ciencias Forestales y Centro de Biotecnología, Casilla 160 C, Concepción, Chile. "Corresponding author (esanfuen@udec.cl).

Received: 24 November 2009.

Accepted: 5 March 2010. a serious rotting problem in cuttings associated with high relative humidity and temperature which are conditions required in this plant production system.

Numerous research studies in Canada, the United States, Israel, and Brazil have shown the potential and effectiveness of microorganisms to control B. cinerea, mainly Clonostachys and Trichoderma strains, both in greenhouse and field tests, and obtaining better results in some cases than for recommended fungicides (Sutton and Peng, 1993; Zhang et al., 1994; Elad et al., 1996; Sutton et al., 1997; Sanfuentes and Ferreira, 1997; Wilson, 1997; Yu and Sutton, 1997; Gerlagh et al., 2001; Nobre et al., 2005; Elmer and Reglinski, 2006; Cota et al., 2008).

The possibility of using antagonistic microorganisms in Chile to control $B$. cinerea has been mainly studied in agricultural crops with Trichoderma strains (Esterio and Auger, 2005; Harman et al., 1996; Latorre et al., 1997). On the other hand, a few research studies have been done using this control strategy in forest nurseries (Molina et al., 2006). Given the importance of the disease in Chile and the inherent problems to control it, the objective of this study was to evaluate the effectiveness of Clonostachys and Trichoderma strains to control $B$. cinerea in E. globulus mini-cuttings. 


\section{MATERIALS AND METHODS}

\section{Plant material and experimental conditions}

The experiment was performed at La Posada nursery, Bosques Arauco S.A. (Coronel Road, km 16.5, Bío Bío Region (36 $55^{\prime} 33^{\prime}$ S, 739'10” W). Eucalyptus globulus clonal mini-cuttings $(5-7 \mathrm{~cm})$ were collected from hydroponic hedges to which no fungicide was applied 1 wk before the experiment was established.

The experiment was carried out in a greenhouse with automatic nebulizers to maintain high relative humidity (70-100\%) and an optimal temperature range (20-28 ${ }^{\circ} \mathrm{C}$ ) for mini-cutting rooting in accordance with the company's plant production program. The experiment lasted $45 \mathrm{~d}$ between the end of January and the beginning of March 2006. Dead plants were periodically extracted during the experiment, in accordance with the company's operational control norms.

\section{Inoculum production}

Antagonist strains were transferred to Petri dishes or test tubes with potato dextrose agar medium (PDA, Difco BD, Maryland, USA) and incubated for 15-20 d at $21-24{ }^{\circ} \mathrm{C}$ with a photoperiod of $12: 12 \mathrm{~h}$ to produce inoculum. Conidia were collected in sterile distilled water (SDW). Concentration was adjusted with the help of a hematocytometer (Superior, West Germany).

\section{Treatments}

Five fungi strains were tested, four previously selected as effective antagonists for B. cinerea (Molina et al., 2006), i.e., two Clonostachys (UDC-A10 and UDC-A11) and two Trichoderma (UDC-A27 y UDC-A6), and the fifth was a Trichoderma (EF-1) strain provided by the company. Moreover, two comparison treatments were used: an operational fungicide treatment in the nursery and a control treatment, which consisted in applying only water (corresponding to natural inoculum/infection of pathogen).

Mini-cuttings were submerged in antagonist suspensions for $1 \mathrm{~min}$ in $1 \times 10^{7}$ conidia $\mathrm{mL}^{-1}$ concentration immediately after collection. The fungicide treatment included immersion in cyprodinil + fludioxonil (Switch 62,5 WG, 37.5\% $+25.0 \%$ respectively, Syngenta Agribusiness, Basel, Switzerland) $\left(3 \mathrm{~g} \mathrm{~L}^{-1}\right)$, and minicuttings were maintained in water for the same period of time in the control treatment. Mini-cuttings were placed in the operational substrate of vermiculite and perlite (1:1). Then, antagonists were applied weekly by sprinkling mini-cuttings and watering the substrate at a rate of 5 x $10^{6}$ conidia $\mathrm{mL}^{-1}$. Fungicides used in the sprinklers were selected and applied according to the company's operational gray mold control program, and was applied as follows: Switch, captan (Captan 83 WP, BASF Chile, Santiago, Chile), fenhexamid (Teldor 50\% WP, Bayer CropScience AG, Monheim am Rhein, Germany), iprodione (Rovral 50\% WP, Bayer CropScience A.G.), and Switch measured at $3 \mathrm{~g} \mathrm{~L}^{-1}$ of the commercial product.

A total of five treatments were applied during the experiment on 25 January, 1, 8, 15, and 22 February according to the company's operational gray mold control program. Sprinkling antagonists $(200 \mathrm{~mL}$ per tray) and fungicides $(250 \mathrm{~mL}$ per tray) was done with a manual sprinkler. The substrate was watered only for the antagonist treatments, $5 \mathrm{~mL}$ per mini-cutting with a syringe.

\section{Evaluations}

Disease incidence was evaluated during the experiment by removing dead mini-cuttings every $3 \mathrm{~d}$ (typical stem necrosis) which were deposited in paper bags and maintained at $4{ }^{\circ} \mathrm{C}$. These materials were checked in the Forest Pathology Laboratory with a stereomicroscope (SR, Zeiss, West Germany) in order to verify the presence of $B$. cinerea. Mini-cuttings without any signs of gray mold were taken to a moist chamber to stimulate sporulation and verify the diagnosis.

In the final evaluation of the experiment, all of the plants were collected, and both $B$. cinerea incidence and mini-cutting survival were determined. Disease incidence was calculated as the percentage of dead mini-cuttings to total number analyzed in the treatment. Additionally, rooting of the remaining mini-cuttings was evaluated and expressed as the percentage of the total of surviving mini-cuttings. Mini-cuttings were considered as rooted if they had roots equal or longer than $3 \mathrm{~cm}$ at the time of evaluation.

\section{Experimental design and data analysis}

The experiment was conducted in a randomized complete block design with six replications. An experimental plot consisted of a tray with 88 mini-cuttings, and only 54 central mini-cuttings were considered for the analysis.

Exponential, monomolecular, logistic, Gompertz, and linear models were adjusted to analyze the development of disease incidence over time (Table 1). The model was selected by considering the coefficient of determination $\left(\mathrm{R}^{2}\right)$, mean square for error (MSE), and standard deviation (Campbell and Madden, 1990). Once the best model was obtained, disease progression rates $\left(r_{T i}\right)$ were compared among all curves, and in all of the possible pair combinations.

When the data did not meet normality assumptions (Shapiro-Wilk Test) and variation homogeneity (Bartlett Test) for the statistical analysis of final disease incidence and rooting variables, they were thus transformed using 
Table 1. Models used to analyze the progress of gray mold in Eucalyptus globulus mini-cuttings where $y$ : final inoculum, $y_{0}$ : initial inoculum, $r_{i}$ : disease progress rates, and $t$ : time.

\begin{tabular}{lr}
\hline Model name & Linearized model \\
\hline Exponential & $\ln (y)=\ln \left(y_{o}\right)+r_{E} \cdot t$ \\
Monomolecular & $\ln \left(\frac{1}{1-y}\right)=\ln \left(\frac{1}{1-y_{o}}\right)+r_{M} \cdot t$ \\
$\ln \left(\frac{y}{1-y}\right)$ & $=\ln \left(\frac{y_{o}}{1-y_{o}}\right)+r_{L} \cdot t$ \\
Logistic & $-\ln [-\ln (y)]=-\ln \left[-\ln \left(y_{o}\right)\right]+r_{G} \cdot t$ \\
Gompertz & $y=y_{o}+r_{i} \cdot t$ \\
\hline
\end{tabular}

squared root to fix the problem. All data were analyzed by ANOVA and multiple comparisons by the Least Significant Difference (LSD) Test at $\alpha=0.05$. Analyses were performed by the Statistical Analysis System program (SAS Institute, 2002) and Statistica (StatSoft, 2007).

\section{RESULTS}

According to the symptoms observed in the mini-cuttings, the most frequent place of $B$. cinerea infection was in the zone adjacent to the stem cut in contact with the substrate where the pathogen colonized tissues and advanced towards the apex of the mini-cutting. Affected minicuttings were also observed in the first vertical leaf and in the apex, but this represented only a few cases. It was common to observe mini-cuttings attacked by $B$. cinerea forming callus and/or roots.

\section{Disease incidence and progression rate}

At the end of the experiment, $B$. cinerea incidence in $E$. globulus mini-cuttings showed significant differences among treatments $(\mathrm{p}=0.01)$. The lowest $B$. cinerea incidence was obtained by applying Clonostachys UDC-A11 (14\%) and the highest disease incidence was with Trichoderma UDC-A6 (52\%) (Figure 1). The Clonostachys UDC-A10 and UDC-A11 strains significantly reduced $B$. cinerea incidence with control levels of 54 and $71 \%$, respectively, and had a statistical effect similar to fungicides (61\%). Applying Trichoderma UDC-A6, UDC-A27, and EF-1 resulted statistically similar to the control, with the latter two achieving control levels of 51 and $16 \%$, respectively. The atypical increase of $B$. cinerea incidence at the end of the experiment (Figure 2) was attributed to the fact that some of the minicuttings with gray mold symptoms had not been detected during the partial recording of the disease and continued in the experiment until the final evaluation when all the mini-cuttings were harvested.

Disease progression was adjusted in all treatments to the exponential model (Table 1) and showed the best adjustment parameters: coefficient of determination $\left(\mathrm{R}^{2}\right)$, MSE, and standard deviation. The highest disease progression rate was obtained with the control treatment, and Trichoderma UDC-A6 and EF-1. The comparison between disease progression rates $\left(r_{E}\right)$ (Table 2) showed that the control treatment disease progression rate was statistically different from all other treatments, except Trichoderma EF-1 $(\mathrm{p}=0.1441)$. This strain was also statistically similar to Trichoderma UDC-A6 $(\mathrm{p}=0.4760)$. Disease progression rates for Clonostachys UDC-A10 and Trichoderma UDC-A27 were statically similar ( $\mathrm{p}=$ 0.7136) and lower than the control. Applying Clonostachys UDC-A11 and fungicides significantly reduced the disease progression rate which is statistically similar $(\mathrm{p}=0.1630)$

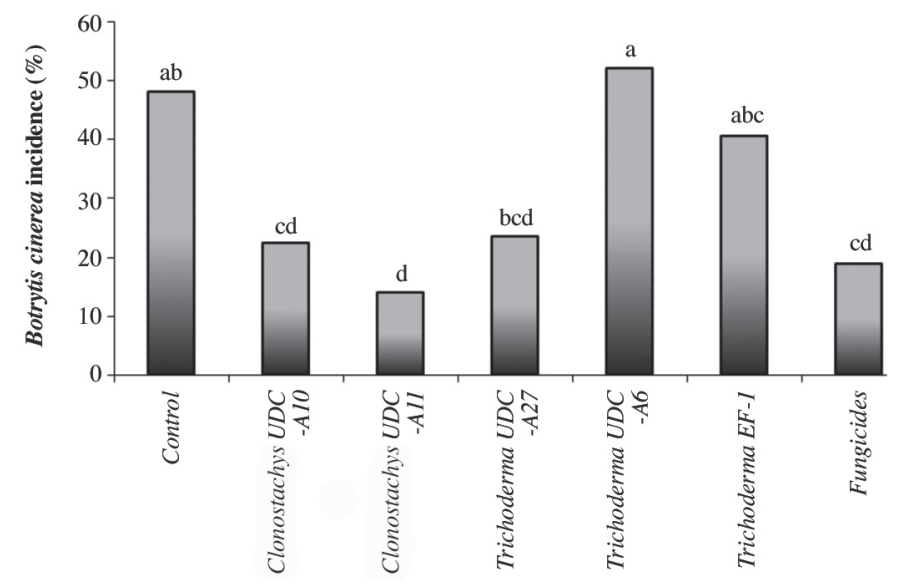

Different letters indicate significant differences according to LSD Test $(\alpha=0.05)$.

Figure 1. Botrytis cinerea incidence in Eucalyptus globulus mini-cuttings at the end of the experiment. 


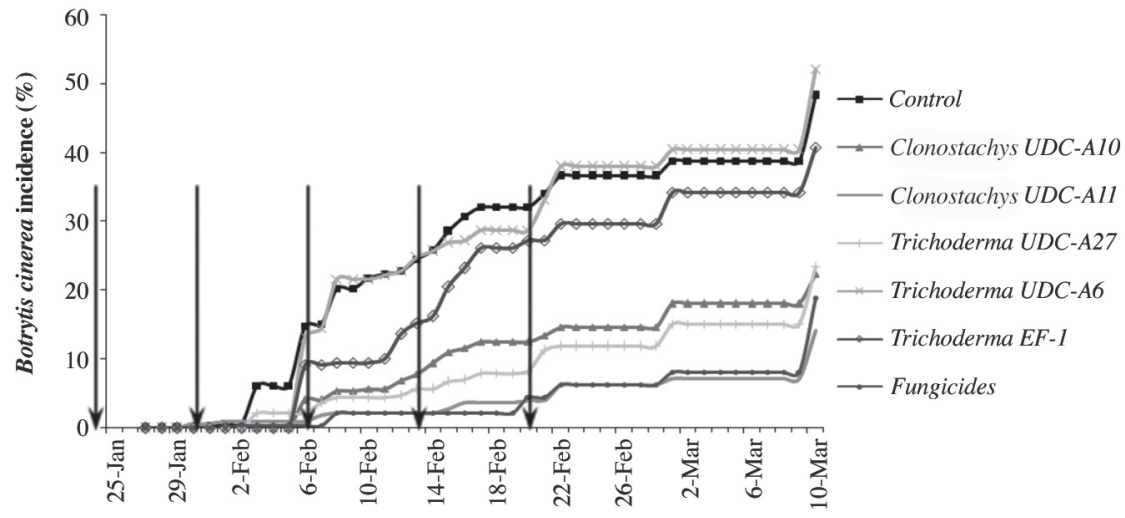

Figure 2. Evolution of Botrytis cinerea incidence in Eucalyptus globulus mini-cuttings during the experiment. Arrows indicate the application of antagonists and fungicides.

in both treatments. These two treatments exhibited similar mini-cutting mortality behavior with the lowest disease incidence and progression rate during the experiment.

\section{Mini-cutting rooting}

Significant differences in mini-cutting rooting between treatments were verified ( $\mathrm{p}<0.0001)$. All antagonist treatments showed no significant differences with the control (80\% rooting). By applying Clonostachys UDC-A10 and UDC-A11, as well as Trichoderma UDC-A27, the highest levels of rooting fluctuated between 88 and $90 \%$ which is significantly different from fungicides (Figure 3). The fungicide treatment exhibited low rooting levels with a reduction of $87 \%$, which was significantly lower than the control and the rest of the applied antagonists.

\section{DISCUSSION}

The Clonostachys UDC-A10 and UDC-A11 strains reduced $B$. cinerea incidence with respect to the control treatment, and obtained control levels of 54 and $71 \%$, respectively. Comparing the effectiveness of control attained by these antagonists and results obtained in other research studies, a moderate to high control effect is possible (Sutton et al., 2002) since there was a naturally high disease pressure during this experiment. Control attained by the antagonists could be attributed to their arriving before the pathogen to plant tissues (Sutton and Peng, 1993; O'Neill et al., 1996) since they were applied immediately after collecting the mini-cuttings. The Clonostachys species action mechanisms have not been completely studied, but it is thought that mycoparasitism, substrate competition, antibiosis, and induced systematic resistance play an important role (Sutton et al., 1997). In addition, it has been shown that $C$. rosea can penetrate without causing damage or deterioration in the host's tissues and act as an endophyte (Sutton and Peng, 1993;
Table 2. Values for initial inoculum $\left(y_{0}\right)$ and disease progression rate $\left(r_{T}\right)$ of Botrytis cinerea during the experiment with Eucalyptus globulus mini-cuttings adjusted according to the exponential model for all treatments.

\begin{tabular}{|c|c|c|}
\hline Variable & Standard deviation & Coefficient $^{*}$ \\
\hline \multicolumn{3}{|l|}{ Control } \\
\hline $\boldsymbol{R}^{2}=0.5128$ & $\mathrm{CME}=1.34528$ & \\
\hline$y_{0}$ & 0.13885 & -4.37154 \\
\hline$r_{T 0}$ & 0.00544 & $0.09129 b$ \\
\hline \multicolumn{3}{|c|}{ Clonostachys UDC-A10 } \\
\hline $\boldsymbol{R}^{2}=0.3979$ & $\mathrm{CME}=1.25100$ & \\
\hline$y_{0}$ & 0.13390 & -4.84787 \\
\hline$r_{T 1}$ & 0.00524 & $0.06975 \mathrm{c}$ \\
\hline \multicolumn{3}{|c|}{ Clonostachys UDC-A11 } \\
\hline $\boldsymbol{R}^{2}=0.2642$ & $\mathrm{CME}=0.89195$ & \\
\hline$y_{0}$ & 0.11306 & -4.67697 \\
\hline$r_{T 2}$ & 0.00443 & $0.04342 \mathrm{~d}$ \\
\hline \multicolumn{3}{|c|}{ Trichoderma UDC-A27 } \\
\hline $\boldsymbol{R}^{2}=0.4861$ & $\mathrm{CME}=0.93881$ & \\
\hline$y_{0}$ & 0.11599 & -4.82267 \\
\hline$r_{T 3}$ & 0.00454 & $0.07229 \mathrm{c}$ \\
\hline \multicolumn{3}{|c|}{ Trichoderma UDC-A6 } \\
\hline$R^{2}=0.6684$ & $\mathrm{CME}=0.95238$ & \\
\hline$y_{0}$ & 0.11683 & -4.69751 \\
\hline$r_{T 4}$ & 0.00457 & $0.10629 a$ \\
\hline \multicolumn{3}{|c|}{ Trichoderma EF-1 } \\
\hline $\boldsymbol{R}^{2}=0.6485$ & $\mathrm{CME}=0.95211$ & \\
\hline$y_{0}$ & 0.11681 & -4.85050 \\
\hline$r_{T 5}$ & 0.00457 & $0.10168 \mathrm{ab}$ \\
\hline \multicolumn{3}{|l|}{ Fungicides } \\
\hline $\boldsymbol{R}^{2}=0.3785$ & $\mathrm{CME}=0.74863$ & \\
\hline$y_{0}$ & 0.10358 & -4.88637 \\
\hline$r_{T 6}$ & 0.00405 & $0.05180 \mathrm{~d}$ \\
\hline
\end{tabular}

*Different letters indicate significant differences between disease progression rates $(\alpha=0.05)$. 


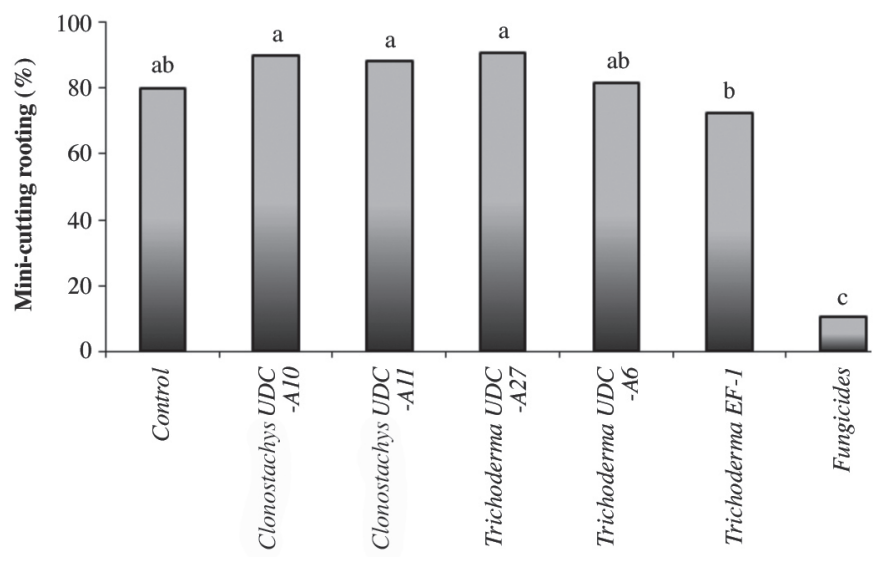

Different letters indicate significant differences according to LSD test $(\alpha=0.05)$.

Figure 3. Rooting of Eucalyptus globulus mini-cuttings in the greenhouse after $45 \mathrm{~d}$.

Zhang et al., 1996; Yu and Sutton, 1997; Morandi et al., 2000), thus giving it an advantage over other biological control agents, such as some bacteria and filamentous fungi which remain on the surface of the plant and must fight against the destructive influences of the phylloplane's micro-climate. Plant production from cuttings requires constant water nebulization which can result in the loss of antagonists on the phylloplane, and leave the tissues unprotected against $B$. cinerea. This may be the reason for which Trichoderma strains were less effective in controlling the disease, unlike Clonostachys strains which could protect tissues from the inside and reach high control levels. The same Trichoderma strains (UDC-A6 and UDC-A27) had better results controlling the same pathogen under different environmental conditions (Molina et al., 2006). Different studies are currently being conducted to explain which antagonism mechanisms are involved in the tested Clonostachys strains.

Adjusting the exponential model to $B$. cinerea incidence in this experiment means that there is a directly proportional relationship between the disease progression rate and disease incidence, and an indirect relationship with the initial inoculum (Campbell and Madden, 1990) (Figure 2). The effect that certain antagonists had in reducing the disease progression rate indicates that biocontrol agents directly affect $B$. cinerea sporulation and reduce secondary inoculum (secondary infections). This result also verifies the importance of the secondary inoculum in this pathosystem, especially since environmental conditions in this experiment were highly favorable to the development of the disease.

In the production of forest plants from seeds, $B$. cinerea typically attacks the apical portion (young tissue or damaged by abiotic factors) or aging leaves attached to the stem (Butin and Peredo, 1986). However, the pathogen in this experiment was observed as mainly attacking the cut zone of mini-cuttings in contact with the substrate and directly affected root development. It is necessary to analyze the control strategy in this pathosystem given this different way of attacking by emphasizing antagonist protection in the stem (neck) and in callus formation zone to better protect the plant, as well as complementing it with traditional strategies to protect the aerial part of the seedlings.

The Clonostachys UDC-A10 and UDC-A11 and Trichoderma UDC-A27 strains obtained higher mini-cutting rooting levels. Certain specific plantmicroorganism interactions can positively influence plant growth through a series of mechanisms in the case of rooting. These effects could be attributed to an increase in tolerance to a different abiotic stress, controlling pathogens, and/or directly or indirectly promoting plant growth and development (Bais et al., 2006). Similar results were observed in research by Oliveira et al. (2007) and Donoso et al. (2008) who used Trichoderma strains to promote plant growth and rooting of $P$. radiata and Eucalyptus sp., respectively. The same effect was observed in miniature roses, geraniums, and cucumbers (plants and cuttings) treated with $C$. rosea which accelerated rooting of the cuttings, increased plant height and root dry mass, accompanied with disease reduction (Sutton et al., 2008). On the other hand, the treatment applying fungicides in this experiment achieved one of the best mini-cutting survival levels. However, there was a negative effect on root formation with only $10 \%$ rooting. The minicuttings in this treatment remained vigorous due to the formation of an abundant undifferentiated tissue mass (callus). Perhaps this means that the rhizogenesis process was delayed rather than root formation being inhibited. A similar effect appeared in geranium stems treated with 
C. rosea and fungicides where the antagonist developed abundant, healthy, and more vigorous roots than those treated with fungicides (Sutton et al., 1997). The effect of antagonists or fungicides on rooting should be accurately established in future tests.

\section{CONCLUSION}

Clonostachys UDC-A10 and UDC-A11 strains were effective in reducing mini-cutting mortality caused by $B$. cinerea during the rooting phase. Moreover, Clonostachys UDC-A11 reduces the disease progression rate with statistical effects similar to those achieved by fungicides. In addition, the greatest rooting values were obtained for mini-cuttings treated with Clonostachys and Trichoderma strains, and applying fungicide had a negative effect on the control treatment.

These results indicate the effectiveness of Clonostachys as a control agent against gray mold in the production of E. globulus mini-cuttings.

\section{ACKNOWLEDGEMENTS}

We thank La Posada Nursery, Bosques Arauco S.A. for supplying plant material, facilities, and trained personnel to carry out this experiment. We are grateful to Dr. Katia Sáez for statistical analysis orientation. We thank the personnel of the Pathology Forest Laboratory for their collaboration in greenhouse activities.

\section{RESUMEN}

Control de Botrytis cinerea en miniestacas de Eucalyptus globulus utilizando cepas de Clonostachys y Trichoderma. Botrytis cinerea Pers. ex Fr. ocasiona la enfermedad conocida como moho gris en más de 200 hospederos. En Chile es uno de los patógenos más importantes en viveros forestales, siendo Eucalyptus globulus Labill. una de las especies más susceptibles, especialmente en los sistemas de reproducción vegetativa. En investigaciones previas, realizadas por los autores, se seleccionaron cepas de Clonostachys y Trichoderma como potenciales agentes de biocontrol del moho gris. El objetivo fue evaluar la eficacia de hongos antagonistas en el control de B. cinerea en mini-estacas de E. globulus. Se probaron cinco cepas de hongos, dos de Clonostachys y tres de Trichoderma $\left(5 \times 10^{6}\right.$ conidias $\left.\mathrm{mL}^{-1}\right)$ aplicados semanalmente. Además, se utilizaron tratamientos para realizar comparaciones: control absoluto (agua) y aplicación de fungicidas. El ensayo se realizó bajo condiciones operacionales de producción de mini-estacas de E. globulus. Las cepas de Clonostachys UDC-A10 y UDC-A11 redujeron la mortalidad de las mini-estacas ocasionada por B. cinerea en $54 \%$ y $71 \%$, respectivamente, con efectos similares a los logrados por los fungicidas. Clonostachys UDC-A11 redujo la tasa de incremento de la enfermedad con resultados estadísticamente similares a los obtenidos con fungicidas. Además, con la aplicación de fungicidas se constató un efecto negativo en el enraizamiento de las mini-estacas sobrevivientes. Estos resultados demuestran la eficacia de Clonostachys como agente de control contra la enfermedad del moho gris en mini-estacas de E. globulus.

Palabras clave: agentes de biocontrol, eucalipto, viveros forestales, moho gris, hongos antagonistas.

\section{LITERATURE CITED}

Bais, H., T. Weir, L. Perry, S. Gilroy, and J. Vivanco. 2006. The role of root exudates in rhizosphere interactions with plants and other organisms. Annual Review of Plant Biology 57:233-266.

Butin, H., y H. Peredo. 1986. Hongos parásitos en coníferas de América del Sur con especial referencia a Chile. 100 p. Bibliotheca Mycologica. Ed. Cramer, Berlín, Alemania.

Campbell, C., and L. Madden. 1990. Introduction to plant disease epidemiology. 532 p. Wiley-Interscience, New York, USA.

Coley-Smith, J., K. Verhoeff, and W. Jarvis. 1980. The biology of Botrytis. 318 p. Academic Press, London, UK.

Cota, L., L. Maffia, E. Mizubuti, P. Macedo, and R. Antunes. 2008. Biological control of strawberry gray mold by Clonostachys rosea under field conditions. Biological Control 46:515-522.

Donoso, E., G. Lobos, and N. Rojas. 2008. Efecto de Trichoderma harzianum y compost sobre el crecimiento de plántulas de Pinus radiata en vivero. Bosque 29(1):52-57.

Elad, Y., N. Malathrakis, and A. Dik. 1996. Biological control of Botrytis-incited diseases and powdery mildews in greenhouse crops. Crop Protection 15:229-240.

Elad, Y., B. Williamson, P. Tudzynski, and N. Delen. 2004. Botrytis: Biology, pathology and control. 403 p. Kluwer Academic Press, Dordrecht, The Netherlands.

Elmer, P., and T. Reglinski. 2006. Review: Biosuppression of Botrytis cinerea in grapes. Plant Pathology 55:155177.

Esterio, M., and J. Auger. 2005. Uso de trichodex en Chile para el control de Botrytis cinerea en uva de mesa. Universidad de Chile, Facultad de Ciencias Agronómicas. Available at http://mazinger.sisib. uchile.cl/repositorio/lb/ciencias_agronomicas/ montealegre_j/4.html (accessed 5 September 2009). 
Gerlagh, M., J. Amsing, W. Molhoek, A. Bosker-van Zessen, C. Lombaers-van der Plas, and J. Köhl. 2001. The effect of treatment with Ulocladium atrum on Botrytis cinerea-attack of geranium (Pelargonium zonale) stock plants and cuttings. European Journal of Plant Pathology 107:377-386.

Harman, G., B. Latorre, E. Agosin, R. San Martín, D. Riegel, P. Nielsen, A. Tronsmo, and R. Pearson. 1996. Biological and integrated control of Botrytis bunch rot of grape using Trichoderma spp. Biological Control 7:259-266.

Latorre, B., E. Agosin, R. San Martín, and G. Vásquez. 1997. Effectiveness of conidia of Trichoderma harzianum produced by liquid fermentation against Botrytis bunch rot of table grape in Chile. Crop Protection 16:209-214.

Molina, G., S. Zaldúa, G. González, y E. Sanfuentes. 2006. Selección de hongos antagonistas para el control biológico de Botrytis cinerea en viveros forestales. Bosque 27(2):126-134.

Morandi, M., J. Sutton, and L. Maffia. 2000. Effects of host and microbial factors on development of Clonostachys rosea and control of Botrytis cinerea in rose. European Journal of Plant Pathology 106:439448.

Nobre, S., L. Maffia, E. Mizubuti, L. Cota, and A. Dias. 2005. Selection of Clonostachys rosea isolates from Brazilian ecosystems effective in controlling Botrytis cinerea. Biological Control 34:132-143.

Oliveira, F., A. Ferreira, M. Kurtz, e S. Todesco. 2007. Promoção de enraizamento de microestacas de um clone de Eucalyptus sp. por Trichoderma spp. Revista Árvore 32:221-228.

O’Neill, T., A. Niv, Y. Elad, and D. Shtienberg. 1996. Biological control of Botrytis cinerea on tomato stem wounds with Trichoderma harzianum. European Journal of Plant Pathology 102:635-643.

Sanfuentes, E., e F. Ferreira. 1997. Avaliação de fungos para biocontrole de Botrytis cinerea em viveiros suspensos de eucalipto. Revista Árvore 21:147-153.

SAS Institute. 2002. Statistical Analysis System program, version 9.00. SAS Institute, Cary, North Carolina, USA. Available at http://www.sas.com (accessed May 2009).
StatSoft. 2007. Statistica data analysis software system, version 8.0. StatSoft, Tulsa, Oklahoma, USA. Available at http://www.statsoft.com (accessed May 2009).

Sutton, J., D. Li, G. Peng, H. Yu, P. Zhang, and R. Valdevenito-Sanhueza. 1997. Gliocladium roseum, a versatile adversary of Botrytis cinerea in crops. Plant Disease 81:316-328.

Sutton, J., W. Liu, R. Huang, and N. Owen-Going. 2002. Ability of Clonostachys rosea to establish and suppress sporulation potential of Botrytis cinerea in deleafed stems of hydroponic greenhouse tomatoes. Biocontrol Science and Technology 12:413-425.

Sutton, J., W. Liu, J. Ma, W. Brown, J. Stewart, and G. Walker. 2008. Evaluation of the fungal endophyte Clonostachys rosea as an inoculant to enhance growth, fitness and productivity of crop plants. Acta Horticulturae 782:279-286. Available at http://www. actahort.org/books/782/782_34.htm (accessed 16 April 2010).

Sutton, J., and G. Peng. 1993. Biocontrol of Botrytis cinerea in strawberry leaves. Phytopathology 83:615621.

Wilson, M. 1997. Biocontrol of aerial plant diseases in agriculture and horticulture: Current approaches and future prospects. Journal of Industrial Microbiology \& Biotechnology 19:188-191.

Yu, H., and J. Sutton. 1997. Morphological development and interactions of Gliocladium roseum and Botrytis cinerea in raspberry. Canadian Journal of Plant Pathology 19:237-336.

Zhang, P., J. Sutton, and A. Hopkin. 1994. Evaluation of microorganisms for biocontrol of Botrytis cinerea in container-grown black spruce seedlings. Canadian Journal of Forest Research 24:1312-1316.

Zhang, P., J. Sutton,W. Tan, and A. Hopkin. 1996. Gliocladium roseum reduces physiological changes associated with infection of black spruce seedlings by Botrytis cinerea. Canadian Journal of Plant Pathology 18:7-13. 